\title{
Strontium dynamics in soil and assimilation by plants during dissolution of conversion chalk
}

\section{Anton Lavrishchev ${ }^{1}$, Andrey Litvinovich ${ }^{1,2}$, Vladimir Bure ${ }^{2,3}$, Olga Pavlova ${ }^{2}$, and Elmira Saljnikov ${ }^{4}$}

1Saint Petersburg State Agrarian University, Peterburgskoe Road 2, Saint Petersburg, 196601, Russian Federation

${ }^{2}$ Agrophysical Research Institute, Grazhdanskii 14, Saint Petersburg, 195220, Russian Federation

${ }^{3}$ Saint Petersburg State University, Universitetskaya nab., 7-9, Saint Petersburg, 199034, Russian Federation

${ }^{4}$ Soil Science Institute, Teodora Drajzera 7, Belgrade, 11000, Serbia

Address correspondence and requests for materials to Anton Lavrishchev, avlavr@rambler.ru

\begin{abstract}
In an experiment carried out on Soddy-podzolic soil, limed with conversion chalk in a wide range of doses, the rate of dissolution of strontium-containing chalk and its effect on soil and plant were studied. Here we show that the complete decomposition of chalk applied to soil is achieved in the 3-4 years after its application. Increase in the concentration of plant available strontium in soil lasts until the chalk is completely dissolved. The dose of applied chalk determined the assimilation of strontium by rapeseed plants. We have found differences in accumulation of strontium by rapeseed in the year of application of chalk and in the third and fourth year of its aftereffect. We conclude that chalkmeliorated soil will generate strontium streams into plants for a longer period. We further propose empirical models that adequately describe: a) the processes of chalk dissolution in the soil; b) the dynamics of the content of strontium compounds accessible to plants in the process of interaction between chalk and soil; c) strontium accumulation in vegetative mass of rapeseed at different stages of chalk dissolution.
\end{abstract}

Keywords: strontium, conversion chalk, empirical models, soil, rapeseed.

\section{Introduction}

Strontium (Sr) is an alkaline earth metal widely distributed in nature and mostly found in intermediate magmatic rocks and in carbonate sediments (KabataPendias and Pendias, 2001). In as early as 1939, Vinogradov found that excessive accumulation of $\mathrm{Sr}$ in osteoarticular and cartilaginous tissues of animals and humans leads to brittleness of bones and deforming osteoporosis (Vinogradov, 1939); children are especially susceptible to the effects of stable strontium (Public Health Statement, 2004.)

Strontium is usually grouped with elements of the third hazard class. It is believed that, in its chemical properties, it is closest to calcium and can replace the latter in biochemical reactions (Kabata-Pendias and Pendias, 2001).

To date, extensive experimental material has been collected in the literature on the Sr content in the soils of the main climatic regions of the former USSR (Litvinovich, 2004). Research has shown that the long-term use of phosphoric fertilizers (Ivanov and Ermohin, 1990; Karpova and Potatuyeva, 2004), strontium-containing ameliorants and industrial wastes in agricultural production can lead to contamination of soils and plants with this element (Semendyaeva and Dobrotvorskaya, 1992; Litvinovich, Pavlova, Lavrishchev, and Vitkovskaya, 2005; Yusan and Erenturk, 2011; Lavrishchev, 2016).
Bure, V., Pavlova, O., and Saljnikov, E. 2018. Dr. Sci, Associate Professor, orcid.org Vladimir Bure, Dr. Sci., Professor, orcid. 0001-5378-007X; Elmira Saljnikov, Ph.D,

Manuscript Editor: Prof. Cezary Kabala, Institute of Soil Science and Environmenta Protection, Wroclaw University of Poland

Received: April 24, 2018;

Revised: August 24, 2018;

Accepted: August 24, 2018;

Copyright: (c) 2018 Lavrishchev et al. This is an open-access article distributed under the terms of the License Agreement with Saint Petersburg State University, which permits to the authors an unrestricted distribution and self-archiving free of charge.

Funding: No funding information provided. Competing interests: The authors have declared that no competing interests exist. 
The ability of agricultural crops to accumulate strontium in their tissues has been established in a number of papers (Khrustaleva, 2000; Lavrishchev, 2016; Myrvang et al., 2017). The transport of strontium in plants has been described in detail (Seregin and Kozhevnikova, 2004; Qi et al., 2015). Information on the concentration of strontium in plants of different biological families has also been published (Litvinovich, Pavlova, Maslova, and Lavrishchev, 2000; Litvinovich, Lavrishchev, and Pavlova, 2013).

Nevertheless, there is no literature on the dynamics of the content of strontium available for plants in soils during the dissolution of strontium-containing ameliorants introduced over a wide range of doses. There is no data on the level of accumulation of stable strontium by the same species of plants at different stages of dissolution of the calcareous material.

The objectives of the present study included:

- to establish the particle-size distribution of ameliorant - conversion chalk (CC);

- to determine the rate of dissolution of CC in soil treated by increasing doses of ameliorant and to develop empirical models of the process of chalk dissolution;

- to study the dynamics of the plant-available content of strontium in the soil as the CC dissolves over a wide range of doses and to develop empirical models of the dynamics of changes in the Sr content in the soil in a long aftereffect;

- to determine the parameters of Sr accumulation by rapeseed grown on CC meliorated soil at different stages of ameliorant dissolution and to develop empirical models of Sr intake by plants.

\section{Materials and methods}

The rate of conversion chalk (CC) dissolution in the soil, the dynamics of plant-available Sr content, and the parameters of Sr intake in spring rape tissues from soil treated with increasing chalk doses were studied in a 24 -variants vegetative precision experiment.

One of the features of precision experiments is a significant increase in the number of variants due to the elimination of replications (Lauk, Lauk, and Lauk, 2004). In our experiment this allowed us to obtain enough data to determine the precise amount of $\mathrm{Sr}$ accumulation in spring rape grown on soil meliorated by chalk over a wide range of doses at various stages of its dissolution, and to develop empirical models that adequately describe the process of $\mathrm{Sr}$ absorption by this culture.

In the experiment we chose an acid Soddy-podzolic sandy loamy soil (Umbric Albeluvisols Abruptic) from a natural perennial meadow; the soil had the following physicochemical parameters: $\mathrm{pH}(\mathrm{KCl}) 4.1$; hydrolytic acidity (Ha) $-5.4 \mathrm{mmol}(\mathrm{eq}) / 100 \mathrm{~g}$ of soil; content of organic carbon - $1.75 \%$; content of particles less than $0.01 \mathrm{~mm}-18.6 \%$; total content of $\mathrm{Sr}-135 \mathrm{mg} / \mathrm{kg}$ of air-dry soil mass; concentration of mobile forms of strontium $-5 \mathrm{mg} / \mathrm{kg}$ of soil mass.

In the experiment, the plants were sown in pots containing $5 \mathrm{~kg}$ soil. We used a crop alternation of spring rape - vetch - barley - spring rape - spring rape. The crops were fertilized with $0.2 \mathrm{~g}$ NPK per $1 \mathrm{~kg}$ of soil in the form of $\mathrm{NH}_{4} \mathrm{H}_{2} \mathrm{PO}_{4}+\mathrm{NH}_{4} \mathrm{NO}_{3}+\mathrm{KCL}$ (NPK: 16:16:16). Rapeseed and vetch were harvested at the flowering phase, and barley was harvested in the phase of full ripeness.

As an ameliorant in the experiment, a conversion chalk (CC) was used as a by-product of the nitrate treatment of phosphate raw materials in the production of complex mineral fertilizers. The neutralizing capacity of the chalk $\left(\mathrm{CaCO}_{3}\right.$ content) was $90 \%$, the content of stable $\mathrm{Sr}$ was $1.5 \%$.

The amount of unreacted carbonates in the soil was established annually after harvesting the plants using a portable calcimeter (PAK-1, Alekseyev,Subbotin, Hnalkov, and Kravchenko, 1991), where the amount of carbonates is calculated from the flux of $\mathrm{CO}_{2}$ emitted after reaction of soil $\mathrm{CaCO}_{3}$ with $\mathrm{HCl}$. The mobile forms of $\mathrm{Sr}$ from the soil were recovered by acetate-ammonium buffer $(\mathrm{AAB})$ with $\mathrm{pH} 4.8$, which corresponds to the $\mathrm{pH}$ of the root exudates and therefore is considered the available form of $\mathrm{Sr}$ compound closest to the plant. Hydrolytic acidity was determined after treatment of soil with $1 \mathrm{~N} \mathrm{CH}_{3} \mathrm{COONa}$ solution, where the newly formed acetic acid was titrated with base.

Plant digestion was carried out in a mixture of hydrochloric and nitric acid at a ratio of 3:1. Concentration of $\mathrm{Sr}$ in the extracts was determined on an atomic absorption spectrophotometer in the acetylene-air flame after introduction of the $\mathrm{LaCl}_{3}$ solution into the prepared samples. The data of the study were statistically processed (Yakushev and Bure, 2003; Bure, 2007).

\section{Results and Discussion}

\section{CHARACTERISTICS, DISSOLUTION AND DYNAMICS OF CONVERSION CHALK}

Because the rate of dissolution of calcareous fertilizers depends on its particle size (Litvinovich and Nebolsina, 2012), the chalk was passed through a column of sieves with different hole diameters to establish its particle-size distribution (Table 1).

The study has shown that the chalk is characterized by a finely dispersed composition and almost entirely passes through a sieve with a hole diameter of $0.25 \mathrm{~mm}$. The fractions less than $0.05 \mathrm{~mm}$ accounted for $27.2 \%$. The finely dispersed composition of chalk predetermined the high rate of its dissolution in the soil. 
Table 1. Particle - size distribution of conversion chalk, \%

\begin{tabular}{c|c|c|c|c|c|c}
\hline $\mathbf{2} \mathbf{~} \mathbf{~ m m}$ & $\mathbf{2 - 1} \mathbf{~ m m}$ & $\mathbf{1 - 0 . 2 5} \mathbf{~ m m}$ & $\mathbf{0 . 2 5}-\mathbf{0 . 1 6} \mathbf{~ m m}$ & $\mathbf{0 . 1 6}-\mathbf{0 . 0 9} \mathbf{~ m m}$ & $\mathbf{0 . 0 - 0 . 0 6 3 m m}$ & $<\mathbf{0 . 6 3 m m}$ \\
\hline ND & 0.3 & 0.16 & 4.3 & 24.3 & 41.3 & 21.6 \\
\hline
\end{tabular}

Table 2. Dependence of the content of unreacted carbonates on the dose of CC, mg/pot

\begin{tabular}{|c|c|c|c|c|}
\hline \multirow{2}{*}{ Treatment } & \multirow{2}{*}{ Dose of $\mathrm{CaCO}_{3}$} & \multicolumn{3}{|c|}{ Content of carbonates by the years of the research* } \\
\hline & & $1^{\text {st }}$ year & $2^{\text {nd }}$ year & $3^{\text {rd }}$ year \\
\hline control (NPK) & 0 & - & - & - \\
\hline control+ CC $0.1 \mathrm{Ha}$ & 1350 & $108(8.0 \%)$ & Traces & traces \\
\hline control + CC $0.2 \mathrm{Ha}$ & 2700 & $360(13.3 \%)$ & $198(7.3 \%)$ & traces \\
\hline control + CC $0.3 \mathrm{Ha}$ & 4050 & $535(13.2 \%)$ & $378(9.3 \%)$ & traces \\
\hline control + CC $0.4 \mathrm{Ha}$ & 5400 & $630(11.7 \%)$ & $533(9.9 \%)$ & traces \\
\hline control + CC $0.5 \mathrm{Ha}$ & 6750 & $675(10.0 \%)$ & $486(7.2 \%)$ & traces \\
\hline control + CC $0.6 \mathrm{Ha}$ & 8100 & 853 (10.5 \%) & $345(4.3 \%)$ & traces \\
\hline control + CC $0.7 \mathrm{Ha}$ & 9450 & $756(8.0 \%)$ & $302(3.2 \%)$ & traces \\
\hline control + CC $0.8 \mathrm{Ha}$ & 10800 & $864(8.0 \%)$ & $432(4.0 \%)$ & traces \\
\hline control + CC $0.9 \mathrm{Ha}$ & 12150 & $891(7.3 \%)$ & $518(4.3 \%)$ & traces \\
\hline control + CC $1.0 \mathrm{Ha}$ & 13500 & $1116(8.3 \%)$ & $630(4.7 \%)$ & traces \\
\hline control + CC $1.1 \mathrm{Ha}$ & 14850 & $1309(8.8 \%)$ & $515(3.5 \%)$ & traces \\
\hline control + CC $1.2 \mathrm{Ha}$ & 16200 & ND & ND & ND \\
\hline control + CC $1.3 \mathrm{Ha}$ & 17550 & ND & ND & ND \\
\hline control + CC $1.4 \mathrm{Ha}$ & 18900 & 1850 (9.8\%) & $226(1.2 \%)$ & traces \\
\hline control + CC $1.5 \mathrm{Ha}$ & 20250 & $3132(15.5 \%)$ & $351(1.7 \%)$ & traces \\
\hline control + CC $1.6 \mathrm{Ha}$ & 21600 & 4953 (22.9 \%) & $576(2.7 \%)$ & traces \\
\hline control + CC $1.7 \mathrm{Ha}$ & 22950 & $6120(26.7 \%)$ & $275(1.2 \%)$ & traces \\
\hline control + CC $1.8 \mathrm{Ha}$ & 24300 & 3596 (14.8 \%) & $324(1.3 \%)$ & traces \\
\hline control + CC $1.9 \mathrm{Ha}$ & 25650 & $4890(19.0 \%)$ & $752(2.9 \%)$ & traces \\
\hline control + CC $2.0 \mathrm{Ha}$ & 27000 & 7308 (27.0 \%) & $864(3.2 \%)$ & $576(2.1 \%)$ \\
\hline control + CC $2.2 \mathrm{Ha}$ & 29700 & $11325(38.1 \%)$ & 3061 (10.3 \%) & $712(2.4 \%)$ \\
\hline control + CC $2.5 \mathrm{Ha}$ & 33750 & $10845(32.1 \%)$ & 1201 (3.6 \%) & $225(0.7 \%)$ \\
\hline control + CC $3.0 \mathrm{Ha}$ & 40500 & 23814 (58.8 \%) & 13284 (32.8\%) & $648(1.6 \%)$ \\
\hline
\end{tabular}

* in parentheses - \% from applied amount. In the fourth and the fifth year the presence of unreacted carbonates was not established.

CC - conversion chalk; NPK - nitrogen, phosphorus, potassium fertilizer; Ha - hydrolytic acidity; ND — not determined

The results indicated that chalk has high chemical activity (Table 2). By the end of the first year of study, in the pots chalked with $0.1-1.5 \mathrm{Ha}, 84.5$ to $92.7 \%$ of the ameliorant was dissolved. At doses exceeding $1.5 \mathrm{Ha}$, the amount of unreacted carbonates ranged from 14.8 to $58.8 \%$.

Two years after liming, the residual amount of unreacted carbonates in the pots covering the range of chalk doses from $0.2-2.0$ Ha ranged from 1.2 to $9.9 \%$ of the applied amount. In the treatments with chalk doses corresponding to 2.2 and $3.0 \mathrm{Ha}$, the content of unreacted ameliorant was 10.3 and $32.8 \%$.

By the end of the third year, the reaction had ceased in almost all the treatments, except for the pots treated with double and triple doses of chalk, where the complete dissolution of high doses of ameliorant was achieved in the fourth year after application. 


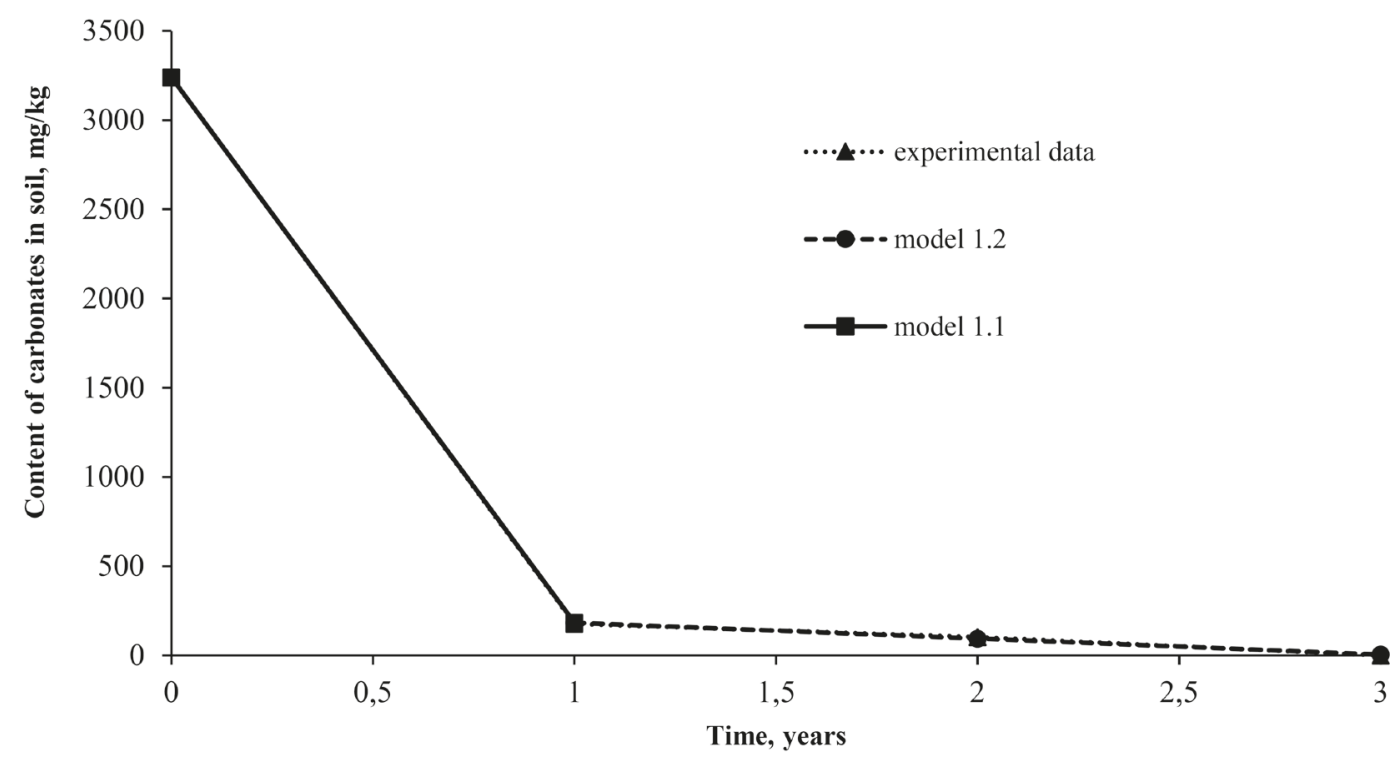

Fig. 1. Model of conversion chalk (CC) dissolution, applied in a dose of 0.9 hydrolytic acidity (Ha)

\section{EMPIRICAL MODELS OF CHALK DISSOLUTION IN SOIL}

Based on the obtained data, mathematical models of ameliorant dissolution in soil were developed. For the calculations, we chose the treatments with doses of CC corresponding to $0.9 \mathrm{Ha}$ by hydrolytic acidity and a deliberately overestimated dose corresponding to $2.5 \mathrm{Ha}$.

Models of dissolution of conversion chalk at a dose of $0.9 \mathrm{Ha}$ are shown in Fig. 1. In the dynamics of the studied indicator, i.e. the content of "free" carbonates, two stages were identified. In the first stage there was a sharp drop in the content of unreacted carbonates in the period from the application of lime to the end of the first year; in the second stage (first to third years), the decrease in this index occurred relatively slowly.

Individual models were developed for each stage. For the treatment with application of CC in a dose of $0.9 \mathrm{Ha}$, the model (1.1) corresponds to stage 1, and the model (1.2) to stage 2 . At point $t=1$, the numerical values of the models coincide. Thus, the combined model $(1.1)+(1.2)$ is a continuous function defined on the time interval from the application point to the end of the third year.

When constructing the model, the numerical values of added amount of carbonates were logarithmized in the treatment using $0.9 \mathrm{Ha}$ dose of $\mathrm{CC}$, and the logarithm of the numerical value of the model (1.2) was found at $t=1$. Further, a polynomial of the first degree was constructed from two points by linear regression analysis (least squares), followed by the inverse transformation. The model (1.1) has the form:

$$
y(t)=\exp (8.08-2.87 \times t),
$$

where $y(t)$ residual carbonate content in soil, $\mathrm{mg} / \mathrm{kg} ; t-$ duration of dissolution of CC, years.
The model (1.2) was constructed by the method of pairwise linear regression (least squares method):

$$
y(t)=272-89 \times t .
$$

The choice of a pairwise linear regression (without a logarithm) for constructing the model was determined by the zero value of the exponent at $t=3$. The coefficient of determination and the value of $F$-statistics testify to the statistical significance of the constructed model at a significance level of $7 \%$ and a very good quality of approximation $\left(R^{2}=0.99, F=105.6\right)$ (Fig. 1).

The dynamics of the content of "free" carbonates in the $2.5 \mathrm{Ha}$ treatment in two stages were also outstanding. In the first stage, a sharp drop in the content of "free" carbonates occurred in the interval from the application to the end of the first year. In stage two (first to third years) there was a relatively slow decrease in this index. For each stage, individual models were constructed: model (2.1) corresponds to stage 1 and model (2.2) corresponds to stage 2 .

The numerical values of the added amount of carbonates in the treatment using $2.5 \mathrm{Ha}$ CC were logarithmized, and the logarithm of the numerical value of the model (2.2) at $t=1$ was found. Then a polynomial of the first degree was constructed on two points by the method of linear regression analysis (least squares method), after which the inverse transformation was applied. As a result, the model (2.1) has the form:

$$
y(t)=\exp (9.12-1.51 \times t),
$$

where $y(t)$ - residual carbonate content in soil, $\mathrm{mg} / \mathrm{kg}$, $t$ - duration of dissolution of CC, years.

For the construction of model 2.2, a logarithm of the numerical data of the content of "free" carbonates in the time interval from the first to the third years was 


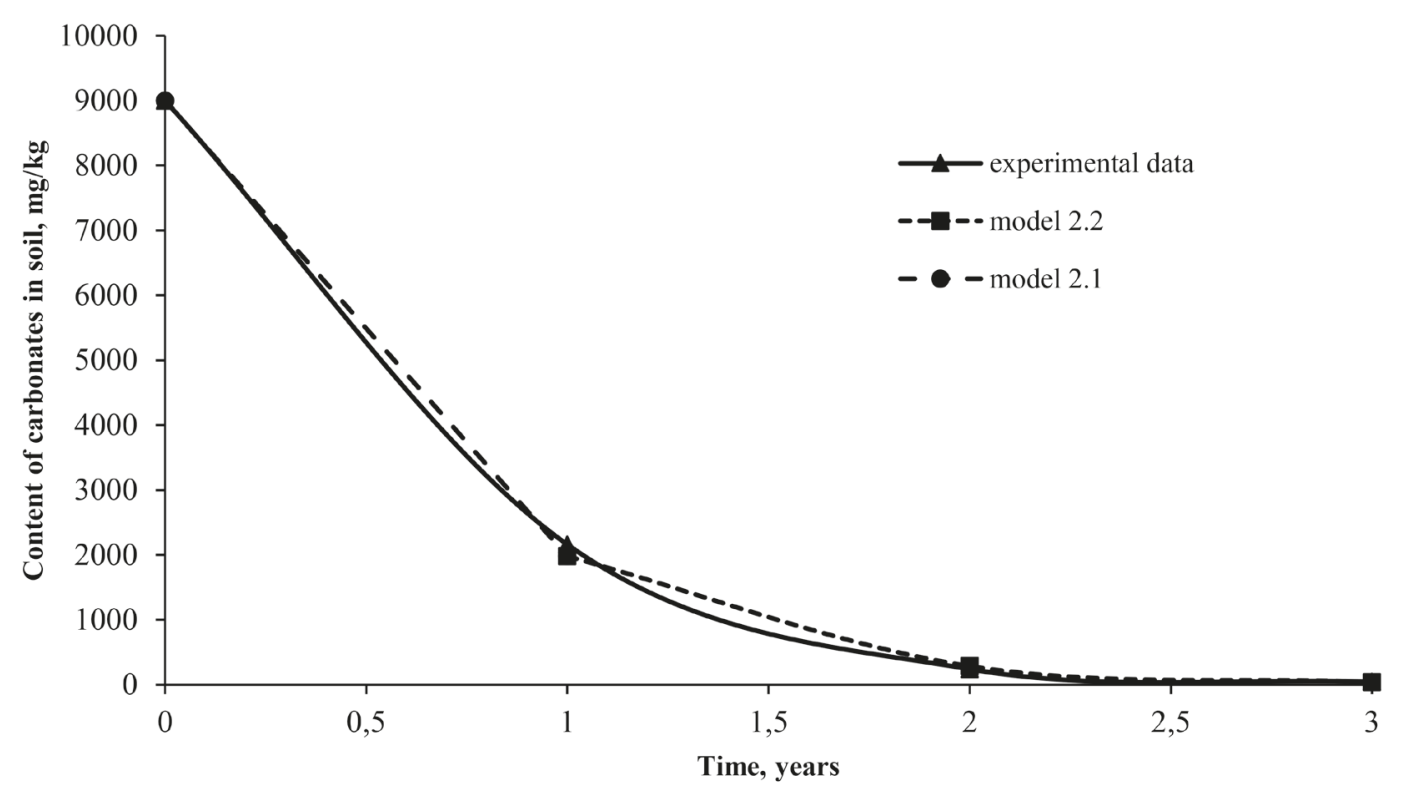

Fig. 2. Model of conversion chalk (CC) dissolution, applied in a dose of 2.5 hydrolytic acidity ( $\mathrm{Ha})$

calculated, and using the linear regression analysis, a pairwise linear regression was constructed, and then the inverse transformation was applied. As a result, the model (2.2) has the form:

$$
y(t)=\exp (9.52-1.94 \times t),
$$

where $y(t)$ - residual carbonate content in soil, $\mathrm{mg} / \mathrm{kg}$, $t$ - duration of dissolution of CC, years.

The regression well describes the data after the logarithm $\left(R^{2}=0.99, F=164\right.$ at $\left.5 \%\right)$ (Fig. 2). Both models correctly characterize the dynamics of the residual carbonate content in the soil over the entire period of dissolution of the ameliorant and are consistent with the experimental data obtained.

The results indicate that dissolution of conversion chalk in soil is a long-lasting process that can be divided into two stages. In the first stage, intensive interaction with the soil occurs; in the second stage a smooth decrease in the amount of unreacted carbonates is observed. Complete dissolution of high chalk doses is achieved at four years after its application.

\section{UPTAKE OF STRONTIUM BY PLANTS}

Liming with CC led to an accumulation of plant-available $\mathrm{Sr}$ in the soil (Table 3). The higher the dose of applied chalk, the more strontium was contained in the soil. However, this pattern was not always observed, especially in the first year of the experiment, when the concentration of $\mathrm{Sr}$ in the treatment with $1 \mathrm{Ha}$ of chalk was $43 \mathrm{mg} / \mathrm{kg}$ of air-dry soil, and in the treatment with $1.1 \mathrm{Ha}-35 \mathrm{mg} / \mathrm{kg}$. This requires a special explanation. As reported in an earlier paper, during $\mathrm{pH}$ determination an ingress of unreacted calcium and magnesium carbonates into the soil resulted in their dissolution in
$1 \mathrm{~N} \mathrm{KCl}$ (Litvinovich and Pavlova, 2010), which resulted in the overestimated results. The more unreacted carbonates enter the flask, the higher the $\mathrm{pH}$ value determined in the salt suspension.

A similar phenomenon happened in this case. Upon entering the flask, part of the non-dissolved chalk decomposed when treated with $\mathrm{AAB}$ ( $\mathrm{pH} 4.8$ ), resulting in overestimated values. Thus, judging the true concentration of calcium and strontium in the soil is possible only after complete dissolution of the chalk.

The increase in the concentration of stable $\mathrm{Sr}$ in the soil of most treatments continued until complete dissolution of chalk (third year). In the third year after liming, its concentration in the soil increased by 1.1-3.0 times, depending on the treatment. It should, however, be borne in mind that an additional source of soil contamination was applied fertilizer, which contained $125 \mathrm{mg} / \mathrm{kg}$ of strontium.

In the fourth and fifth years, the concentration of $\mathrm{Sr}$ in the soil is somewhat reduced. Judging by the amount of $\mathrm{Sr}$ available for plants at the end of the experiment, limed soil in most treatments will continue to generate Sr fluxes into plants. This is confirmed by the data of the migration capacity of Sr. Previous research (Litvinovich, Pavlova, Yuzmukhametov, and Lavrishchev, 2008) showed that in repeated washing of soil, where every wash was modelled for the annual volume of moisture percolating the arable layer, only $25 \%$ of $\mathrm{Sr}$ applied with lime was washed out.

\section{EMPIRICAL MODELS OF THE DYNAMICS OF MOBILE SR}

Mathematical models were constructed based on the data of dynamics of mobile Sr concentration. The treatments limed with 0.9 and $2.5 \mathrm{Ha}$ CC were selected for the calculations (Table 3 ). 
Table 3. The dynamic of Sr concentration depending on the dose of conversion chalk, $\mathrm{mg} / \mathrm{kg}$ of air-dry soil

\begin{tabular}{|c|c|c|c|c|c|}
\hline Treatment & $1^{\text {st }}$ year & $2^{\text {nd }}$ year & $3^{\text {rd }}$ year & $4^{\text {th }}$ year & $5^{\text {th }}$ year \\
\hline control (NPK) & 5 & 8 & 13 & 13 & 18 \\
\hline control + CC $0.1 \mathrm{Ha}$ & 6 & 12 & 19 & 18 & 22 \\
\hline control + CC $0.2 \mathrm{Ha}$ & 9 & 14 & 22 & 18 & 22 \\
\hline control + CC $0.3 \mathrm{Ha}$ & 13 & 19 & 28 & 27 & 28 \\
\hline control + CC $0.4 \mathrm{Ha}$ & 17 & 26 & 32 & 27 & 33 \\
\hline control + CC $0.5 \mathrm{Ha}$ & 24 & 36 & 33 & 28 & 38 \\
\hline control + CC $0.6 \mathrm{Ha}$ & 26 & 30 & 44 & 36 & 39 \\
\hline control + CC 0.7 Ha & 31 & 37 & 50 & 36 & 45 \\
\hline control + CC $0.8 \mathrm{Ha}$ & 24 & 40 & 51 & 41 & 45 \\
\hline control + CC $0.9 \mathrm{Ha}$ & 36 & 48 & 55 & 58 & 54 \\
\hline control + CC $1.0 \mathrm{Ha}$ & 43 & 55 & 65 & 54 & 57 \\
\hline control + CC $1.1 \mathrm{Ha}$ & 35 & 64 & 70 & 60 & 65 \\
\hline control + CC $1.2 \mathrm{Ha}$ & 41 & 79 & 73 & 58 & 69 \\
\hline control + CC $1.3 \mathrm{Ha}$ & 49 & 68 & 79 & 63 & 74 \\
\hline control + CC $1.4 \mathrm{Ha}$ & $\mathrm{H} / \mathrm{O}$ & 84 & 84 & 52 & 78 \\
\hline control + CC $1.5 \mathrm{Ha}$ & 54 & 87 & 89 & 77 & 68 \\
\hline control + CC 1.6 Ha & 53 & 101 & 97 & 81 & 81 \\
\hline control + CC 1.7 Ha & 60 & 98 & 99 & 82 & 86 \\
\hline control + CC $1.8 \mathrm{Ha}$ & 53 & 87 & 106 & 83 & 95 \\
\hline control + CC $1.9 \mathrm{Ha}$ & 54 & 98 & 116 & 94 & 106 \\
\hline control + CC $2.0 \mathrm{Ha}$ & 52 & 124 & 122 & 93 & 95 \\
\hline control + CC $2.2 \mathrm{Ha}$ & 83 & 169 & 147 & 100 & 121 \\
\hline control + CC $2.5 \mathrm{Ha}$ & 84 & 191 & 164.7 & 119 & 136 \\
\hline control + CC $3.0 \mathrm{Ha}$ & 104 & 179 & 187 & 149 & 162 \\
\hline
\end{tabular}

CC — conversion chalk; NPK — nitrogen, phosphorus, potassium fertilizer; Ha - hydrolytic acidity

The model (3.1) is a linear trend of the dynamics of Sr concentration in limed soil $(0.9 \mathrm{Ha})$ :

$$
y_{3.1}=19+9.8 \times t,
$$

where $t-$ time (period). The average rate of dynamics of the index change in the soil limed with a $0.9 \mathrm{Ha}$ dose is $v_{1}=9.8 \mathrm{mg} / \mathrm{kg}$ of soil mass.

The model (3.1) is statistically significant at the $5 \%$ level: the value of $F=14.589$ at the critical value of $F(0.95 ; 1,4)=7.7$ and, therefore, the average speed $v_{1}=9.8 \mathrm{mg} / \mathrm{kg}$ soil mass is also statistically significant (Fig. 3).

The model (3.2) is a polynomial of the third degree:

$$
y_{3.2}=5.48+37.57 \times t-9.43 \times t^{2}+0.82 \times t^{3},
$$

where $t$ - time (period).The model (3.2) is statistically significant at the $5 \%$ level, the value of $F=240$ at the critical value of $F(0.95 ; 3 ; 2)=19.16$ and very closely approximates the observational data $\left(R^{2}=0.99\right)$ (Fig. 3 ).

Thus, in the treatment using a conversion chalk at a dose of $0.9 \mathrm{Ha}$, there was a statistically significant positive dynamic of the studied indicator (a constant increase), with average speed: $v_{1}=9.8 \mathrm{mg} / \mathrm{kg}$ of soil mass. The model (3.2) well describes the experimental data and has a high statistical significance.

The model (4.1) represents a linear trend of the dynamics of Sr concentration in soil limed with $2.5 \mathrm{Ha}$ of CC:

$$
y_{4.1}=64.14+20.94 \times t,
$$

where $t$ - time (period). The average rate of the dynamics of the indicator in the treatment with a $2.5 \mathrm{Ha}$ dose is: $v_{2}=20.94 \mathrm{mg} / \mathrm{kg}$ of soil mass. The model (4.1) is statistically significant at $22 \%(F=2.19$ at the critical value of $\mathrm{F}(0.78 ; 1,4)=2.11)$ (Fig. 4). 


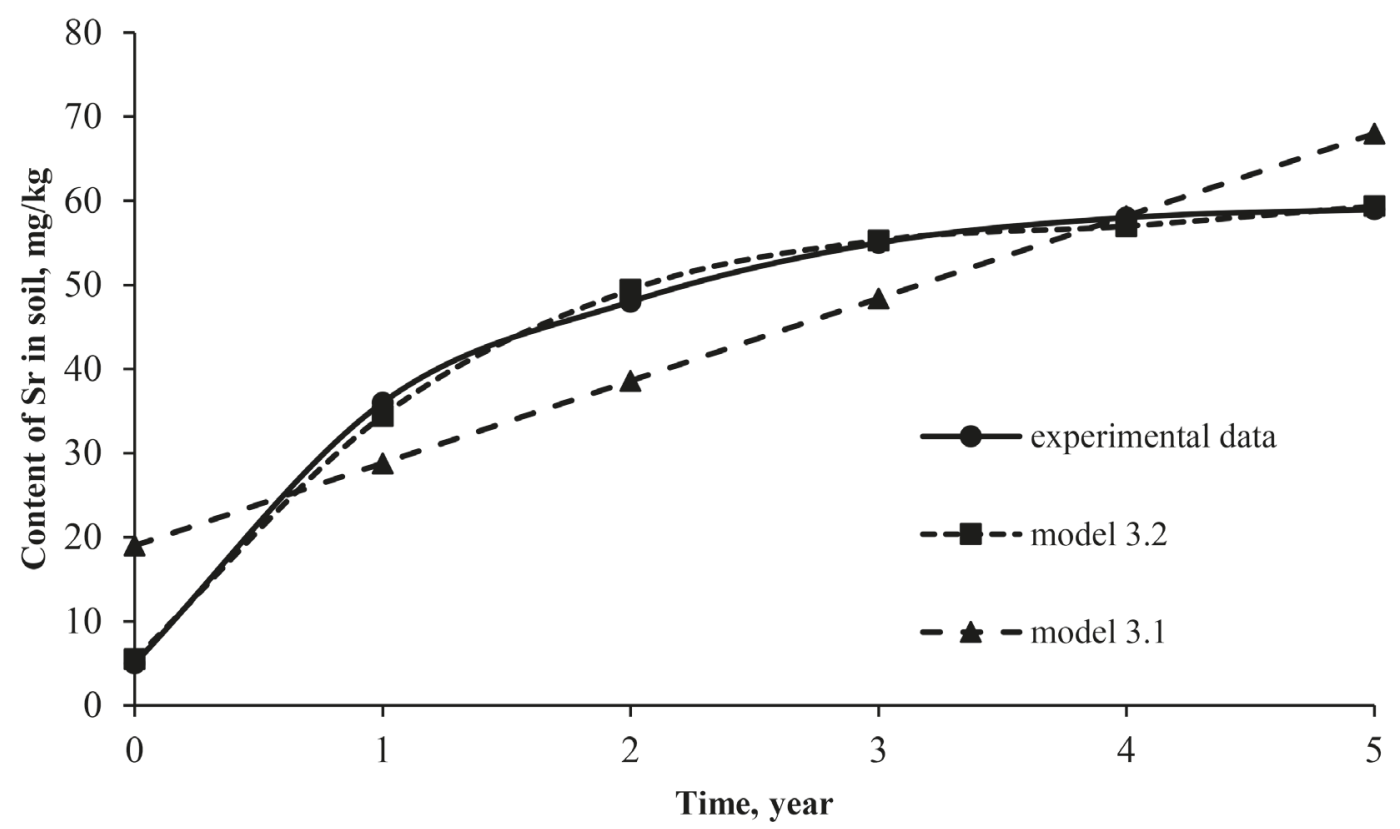

Fig. 3. Dynamic of Sr concentration in soil limed with 0.9 hydrolytic acidity (Ha) conversion chalk (CC)

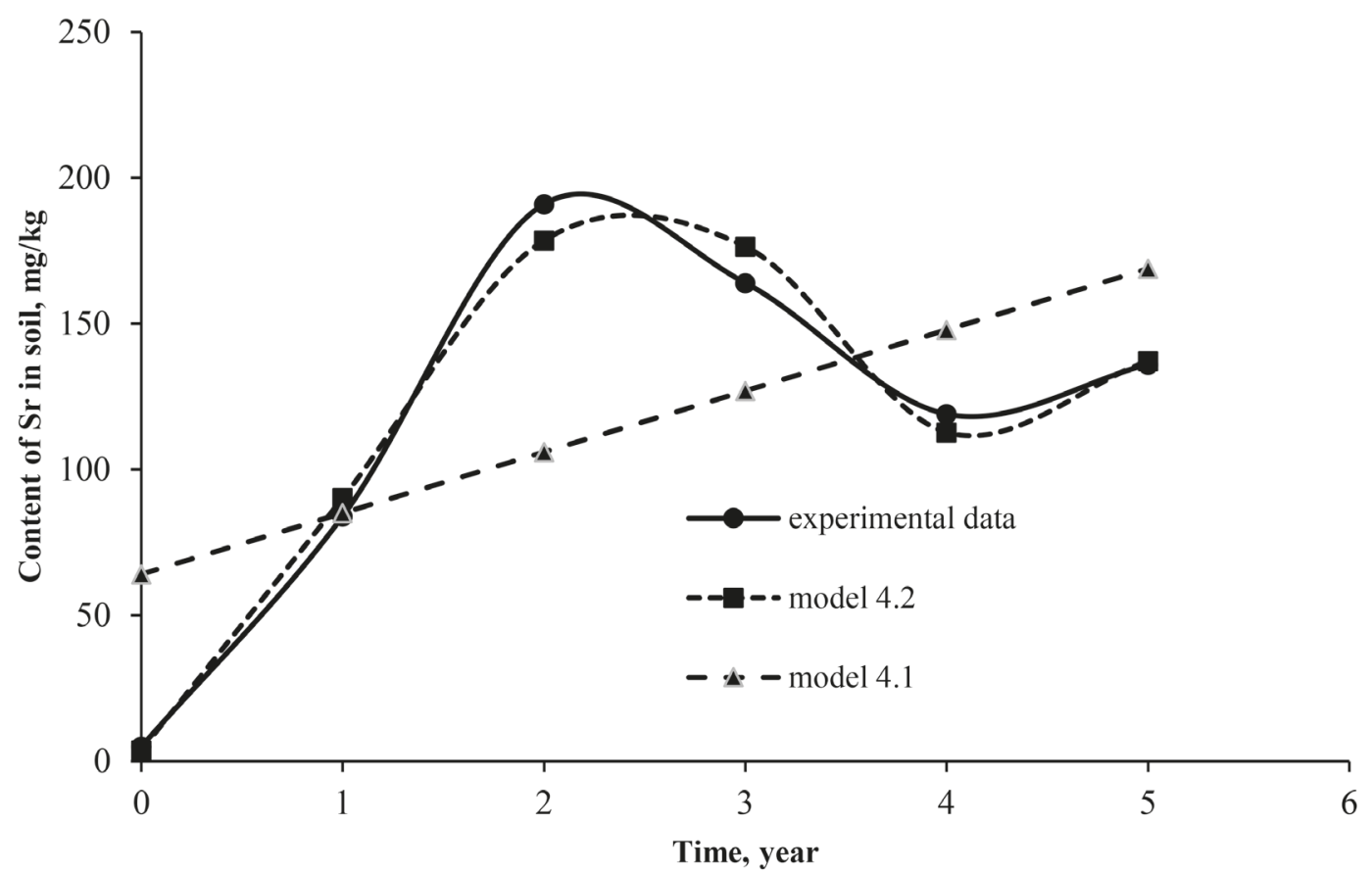

Fig. 4. Dynamic of Sr concentration in soil limed with 2.5 hydrolytic acidity (Ha) conversion chalk (CC)

The model (4.2) is a fourth-degree polynomial:

$$
\begin{gathered}
y_{4.2}=3.75+24.57 \times t+102 \times \\
\quad \times t^{2}-45.6 \times t^{3}+5.04 \times t^{4},
\end{gathered}
$$

where $t$ - time (period). The model (4.2) is statistically significant at the $21 \%$ level $(F=13.6$ at the critical value $F(0.79 ; 4,1)=12.34)$ and very closely approximates the observational data $\left(R^{2}=0.98\right)$ (Fig. 4$)$.

In the treatment limed with $2.5 \mathrm{Ha}$ of CC, there were generally positive dynamics of the indicator (a tendency of erratic increase and positive angular coefficient of the linear trend). Average speed was: $v_{2}=20.9 \mathrm{mg} / \mathrm{kg}$ of soil mass. At the same time, the dynamics of Sr concentration itself are very complex; at certain periods of time both increase and decrease of $\mathrm{Sr}$ concentration was observed. The obtained pattern of the model can be explained by the complexity of the dynamics of exchangeable $\mathrm{Sr}$ in the soil. This requires a special explanation. The solubility of $\mathrm{CaCO}_{3}$ is 1.5 times higher than that of $\mathrm{SrCO}_{3}$ (Spravochnik himika..., 1964). In the second and third years after liming, despite a sharp decrease in the content of "free" carbonates in soil, and up to the fourth year of study, a 
Table 4. Effect of increasing doses of stable Sr on its concentration in rapeseed, $\mathrm{mg} / \mathrm{kg}$ of air-dry plant

\begin{tabular}{|c|c|c|c|}
\hline \multirow{2}{*}{$\begin{array}{l}\text { Applied Sr in soil, } \\
\text { kg/ha }\end{array}$} & \multicolumn{3}{|c|}{ Content of $\mathrm{Sr}$ in rapeseed plants, $\mathrm{mg} / \mathrm{kg}$} \\
\hline & $1^{\text {st }}$ year & $4^{\text {th }}$ year & $5^{\text {th }}$ year \\
\hline 12 & 48 & 173 & 701 \\
\hline 24 & 62 & 170 & 750 \\
\hline 36 & 100 & 203 & 800 \\
\hline 48 & 115 & 230 & 570 \\
\hline 60 & 110 & 240 & 560 \\
\hline 72 & 126 & 763 & 847 \\
\hline 84 & 125 & 840 & 843 \\
\hline 96 & 114 & 930 & 610 \\
\hline 108 & 120 & 1053 & 1040 \\
\hline 120 & 136 & 990 & 850 \\
\hline 132 & 145 & 1150 & 770 \\
\hline 144 & 122 & 990 & 760 \\
\hline 156 & 139 & 1110 & 860 \\
\hline 168 & 110 & 1080 & 970 \\
\hline 180 & 150 & 1110 & 1180 \\
\hline 192 & 170 & 1070 & 1073 \\
\hline 204 & 154 & 1100 & 1240 \\
\hline 216 & 145 & 1160 & 1580 \\
\hline 228 & 154 & 1370 & 1340 \\
\hline 240 & 144 & 1200 & 1330 \\
\hline 264 & 188 & 1310 & 1670 \\
\hline 300 & 234 & 1440 & 1520 \\
\hline 360 & 185 & 1650 & 1690 \\
\hline
\end{tabular}

certain amount of unreacted strontium carbonate remained. During extraction from soil under the action of $\mathrm{AAB}$, an accelerated dissolution of remaining strontium carbonate occurred, which resulted in an overestimation of the results. In the fourth year, after the complete dissolution of chalk in the soil, a decrease in the concentration of exchangeable $\mathrm{Sr}$ in the soil was recorded. The model (4.2) well describes the data of the experiment, but it does not have a high statistical significance due to the insufficient number of observations and the very complex nature of the dynamics of the studied index.

In general, the treatments with the application of CC in doses of 0.9 and $2.5 \mathrm{Ha}$ strongly differ from each other both in the values and the dynamics of Sr, since the average rates of dynamics of $\mathrm{Sr}$ concentration also differ significantly.

The $\mathrm{Sr}$ concentrations in rapeseed plants at different stages of chalk dissolution are summarized in Table 4.
In the year of chalk application, the concentration of $\mathrm{Sr}$ in rapeseed tissues increased from 22 (in the control) to $234 \mathrm{mg} / \mathrm{kg}$ in the treatment using chalk at a dose of $2.5 \mathrm{Ha}$. An increase in the concentration of exchangeable $\mathrm{Sr}$ in the soil in the third and fourth years of aftereffect resulted in an increase in its concentration in the vegetative mass of rapeseed. In the third year of aftereffect, the concentration of Sr in rapeseed varied from 110 to $1650 \mathrm{mg} /$ $\mathrm{kg}$, depending on the treatment. In the fourth year of aftereffect, the range of variation was 487 - $1690 \mathrm{mg} /$ $\mathrm{kg}$. The increased absorption of Sr by rapeseed from the soil of the control variant (without adding chalk) to the fourth and fifth years of the experiment is explained by the calcium deficiency in the soil.

Thus, the effect of Sr entering the soil from CC on the chemical composition of rapeseed is much more pronounced in the fourth and fifth years of the experiment. Differences in absorption are explained by incomplete dissolution of $\mathrm{SrCO}_{3}$ of chalk in the year of liming, which affected the accumulation of this element in different years of rapeseed growth. Consequently, the saturation of plant tissues in different years of study differed, which points out the ecological plasticity of rapeseed.

\section{REGRESSION MODELS OF SR CONCENTRATION IN PLANTS}

According to $\mathrm{Sr}$ concentration in rapeseed plants, three pairs of linear regression models were constructed in different years of the study. As the studied indicator (y) the $\mathrm{Sr}$ concentration in rape $(\mathrm{mg} / \mathrm{kg}$ ) was considered, and as the factor $(\mathrm{x})$ influencing the value of the indicator, the amount of Sr deposited into the soil in individual treatments $(\mathrm{kg} / \mathrm{ha})$ was considered.

The empirical model (5), corresponding to the data of the first year, has the form:

$$
y_{5}=79.05+0.37 \times x,
$$

where $x$ - amount of Sr applied to soil at a time, $\mathrm{kg} / \mathrm{ha}$.

The angular coefficient of the model (5): $a_{5}=0.37 \mathrm{mg} / \mathrm{kg}$ corresponds to the mean value of $\mathrm{Sr}$ increase in rapeseed tissues in an experiment in liming year with an increase in the dose of chalk application by $12 \mathrm{mg} / \mathrm{ha}$.

The statistical properties of the model (5) are very good: $F=62.55$ at the critical value of $5 \%$ significance $F(0.95 ; 1,21)=4.3$; at the critical value corresponding to $1 \%$ significance $F(0.99 ; 1,21)=8.01$. The value of $F$ is many times higher than both critical levels, which indicates a very high statistical significance of the developed empirical model (5) $\left(R^{2}=0.75\right)$ (Fig. 5).

The empirical model (6), corresponding to the data of the fourth year of the experiment, has the form:

$$
y_{6}=292+4.25 \times x \text {, }
$$

where $x$ - amount of Sr applied to soil at a time, $\mathrm{kg} / \mathrm{ha}$. 


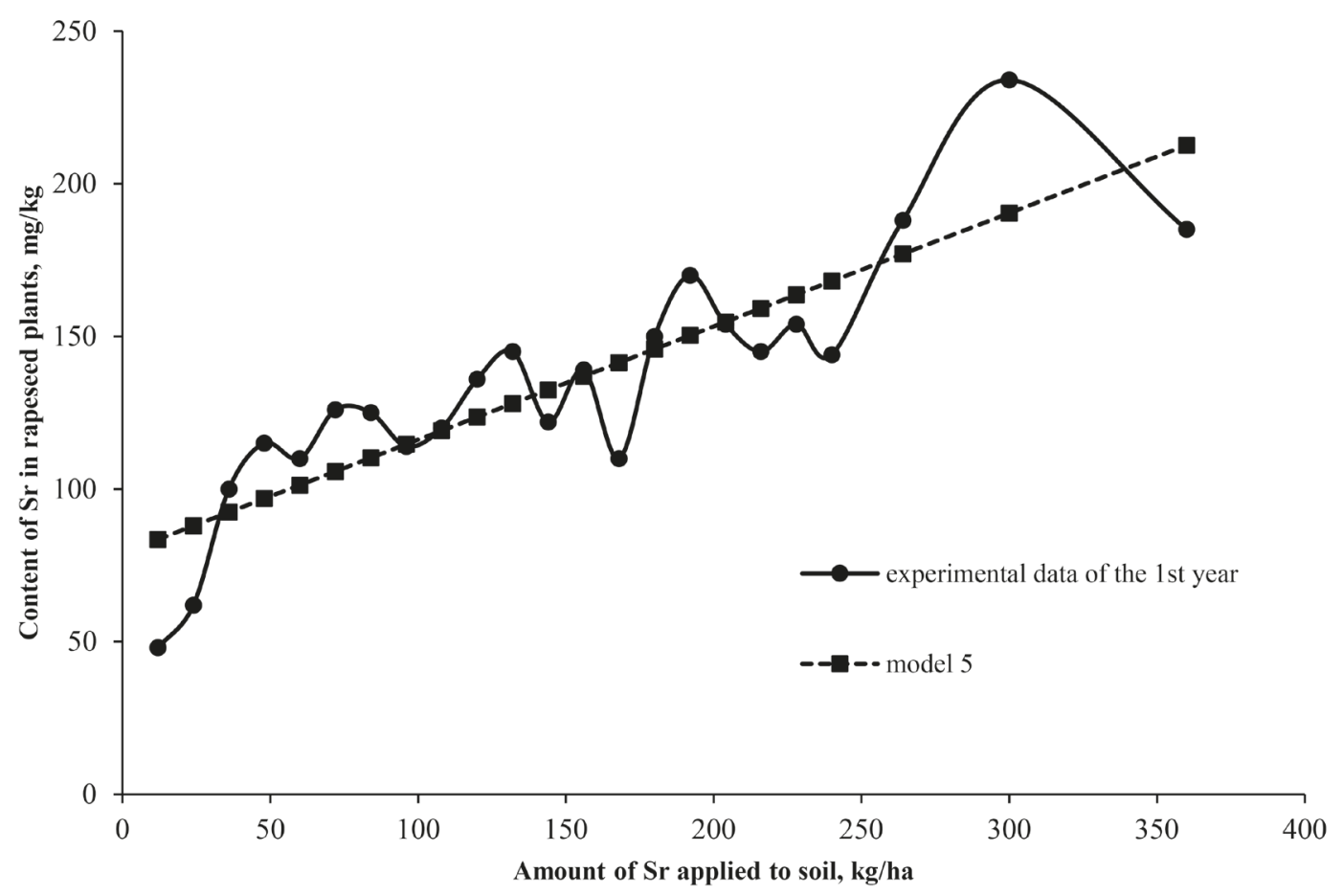

Fig. 5. Variability in Sr concentration in the first year of the experiment

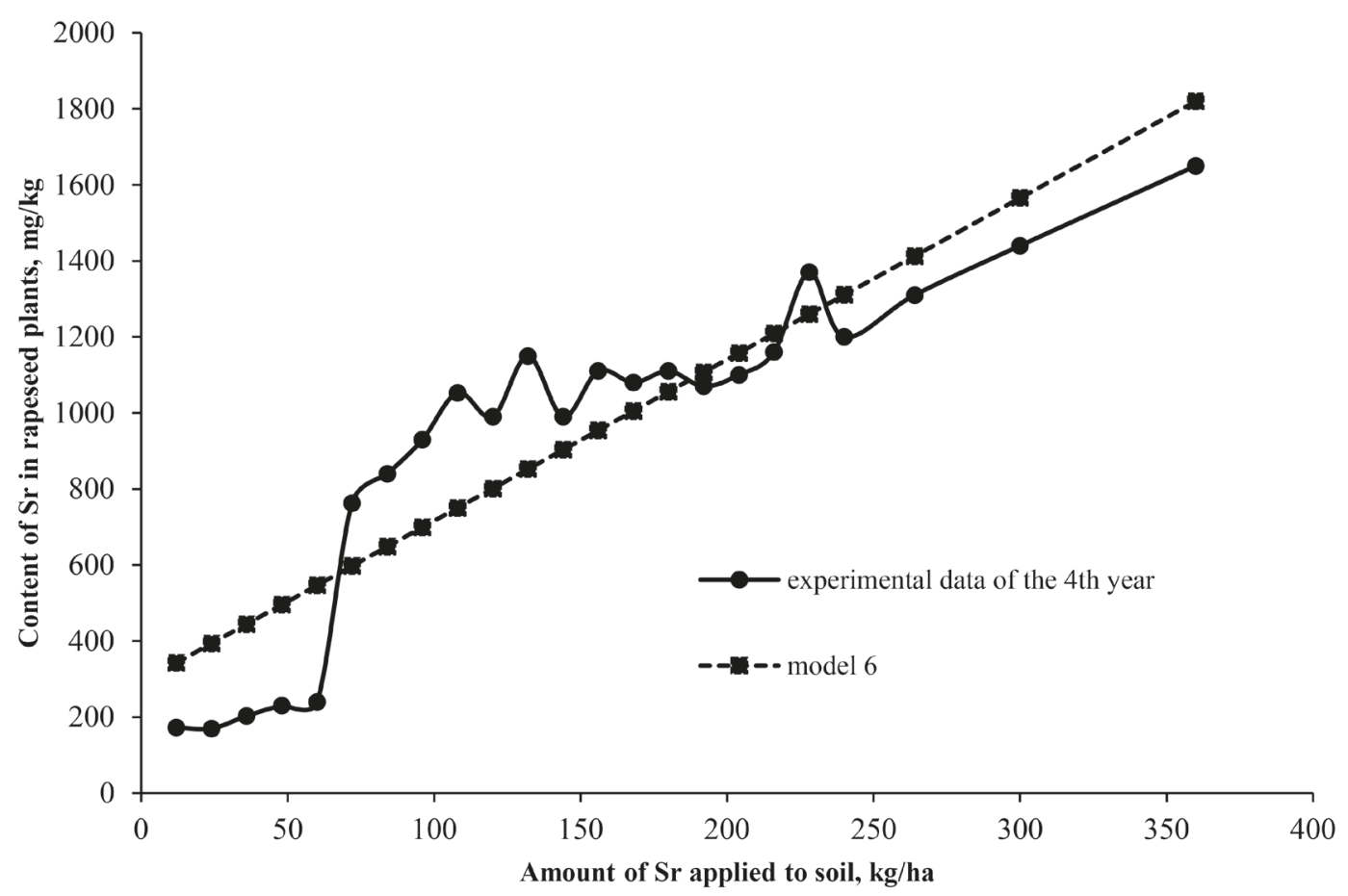

Fig. 6. Variability in $\mathrm{Sr}$ concentration in the fourth year of the experiment

The angular coefficient of the model (6): $a_{6}=4.25 \mathrm{mg} / \mathrm{kg}$ of dry plant mass. The statistics of the model (6) turned out to be better than those of the model (5). The $F=92.8$ at a critical value at $5 \%$ significance level was $\mathrm{F}(0.95 ; 1,21)=4.3$; and at critical value corresponding to a $1 \%$ significance level it was $\mathrm{F}$ $(0.99 ; 1,21)=8.01$. The F-statistics were much greater than both critical levels indicating a very high statisti- cal significance of the developed empirical model (6) $\left(R^{2}=0.82\right)$ (Fig. 6).

The empirical model (7), corresponding to the data of the fifth year, has the form:

$$
y_{7}=507+3.45 \times x,
$$

where $x$ - amount of Sr applied to soil at a time, $\mathrm{kg} / \mathrm{ha}$. 


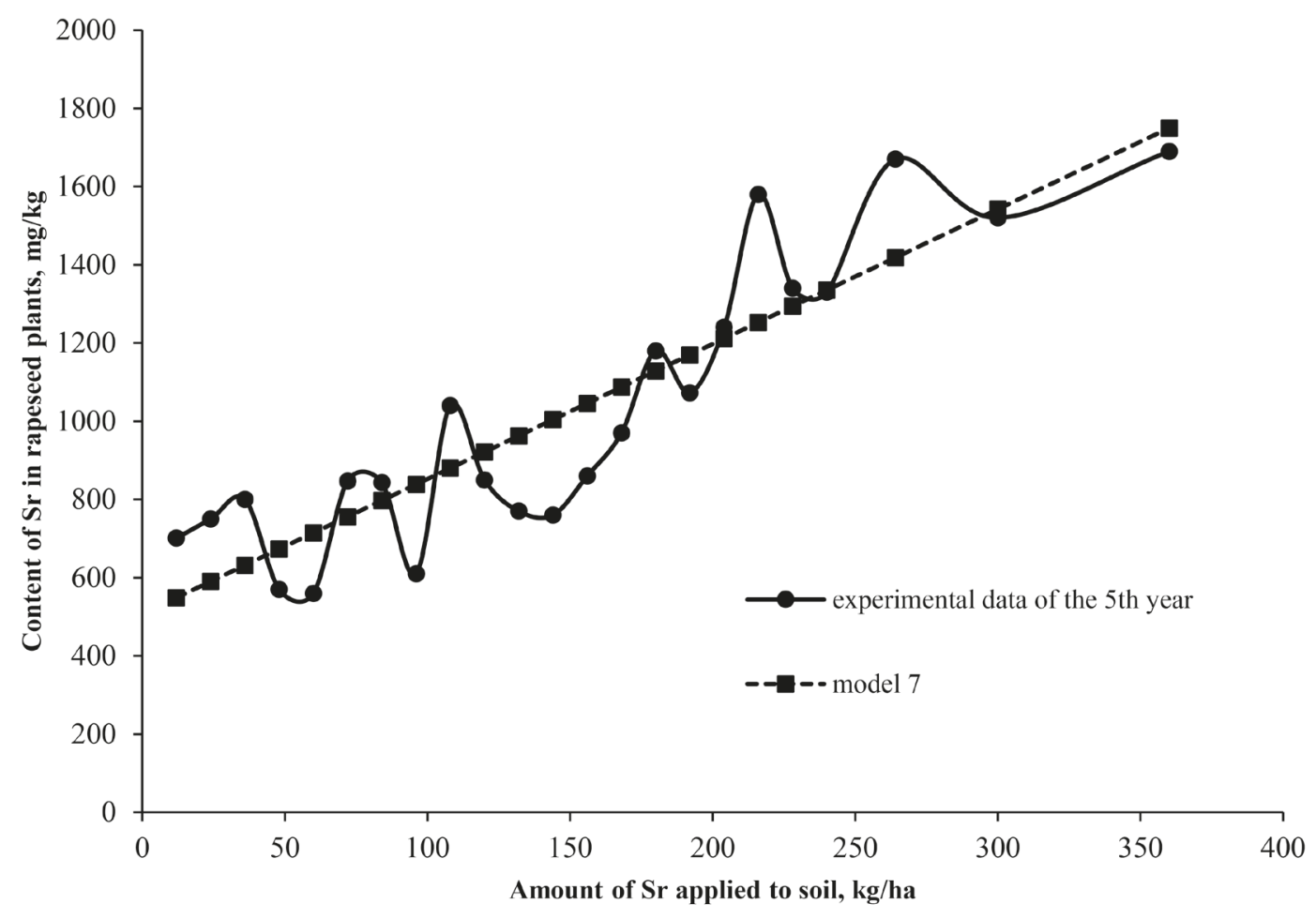

Fig. 7. Variability in Sr concentration in the fifth year of the experiment

The angular coefficient of the model (7): $a_{7}=3.45 \mathrm{mg} / \mathrm{kg}$ of dry plant mass. The statistics of the model (7) are also good. The $F=86.6$ at a critical value at $5 \%$ was $F(0.95 ; 1,21)=4.3$; and at $1 \%$ significance level it was $\mathrm{F}(0.99 ; 1,21)=8.01$. The F-statistics were much greater than both critical levels indicating a very high statistical significance of the constructed empirical model (7) $\left(R^{2}=0.8\right)$ (Fig. 7).

All three empirical models have a high statistical significance and correctly reflect the nature of the dependence of the studied indicator on the explanatory factor. The angular coefficient characterizes the effect of increasing doses of the Sr applied with chalk on the concentration of $\mathrm{Sr}$ in plants. In other words, an increase in the amount of Sr added to the soil of $12 \mathrm{~kg} /$ ha (the step difference between the treatments) leads to an increase in the concentration of $\mathrm{Sr}$ in vegetative mass of rapeseed, on average in the year of liming by $0.37 \mathrm{mg} / \mathrm{kg}$; in the third year of aftereffect of chalk - by $4.25 \mathrm{mg} / \mathrm{kg}$; in the fourth year - by $3.45 \mathrm{mg} / \mathrm{kg}$.

The angular coefficients in models (6) and (7) are much larger than in model (5), therefore, the effect of the amount of Sr applied to soil for fourth and fifth years is much more pronounced than in the year of liming. In the fourth year the angular coefficient is greater than in the fifth year. The differences between the fourth and fifth years are significant.

In general, the developed linear models have very good statistical properties and correctly reflect the var- iability of the studied indicators depending on the applied dose of CC. The quality of linear models turned out to be so high that the developing of some other empirical models seemed inappropriate.

\section{Conclusions}

Conversion chalk has a finely dispersed composition, and $99.7 \%$ of its quantity passed through a sieve with a hole size of $0.25 \mathrm{~mm}$. The fraction less than $0.05 \mathrm{~mm}$ accounted for $27.2 \%$. Under the controlled conditions of a pot experiment, most of the chalk, applied over a wide range of doses, dissolved in the year of application, while complete decomposition of high chalk doses was achieved in the third to fourth years after liming.

Application of chalk resulted in an accumulation of plant-available $\mathrm{Sr}$ in the soil, where the higher dose resulted in higher Sr concentration in the soil. The increase in $\mathrm{Sr}$ concentration in the soil of most treatments continued until the complete dissolution of the chalk. The soil reclaimed with chalk generates streams of plant-available strontium with a long aftereffect.

Rapeseed was characterized by considerable ecological plasticity, and the dose of applied chalk had a decisive influence on the concentration of $\mathrm{Sr}$ in rapeseed tissues. An increase of $\mathrm{Sr}$ concentration applied to soil with chalk resulted in an increase in the concentration of $\mathrm{Sr}$ in rapeseed tissues. In the year of liming, concentration of $\mathrm{Sr}$ in rapeseed varied from 22 to 245; in the 
third year it varied from 110 to 1650 , and in the fourth year - from 487 to $1690 \mathrm{mg} / \mathrm{kg}$ of air-dry plant mass depending on the treatment.

Presented empirical models correctly described the processes of chalk dissolution in soil, the dynamics of plant-available $\mathrm{Sr}$ in the process of interaction between ameliorant and soil, and accumulation of $\mathrm{Sr}$ in vegetative mass of rape at different stages of chalk dissolution.

\section{References}

Alekseyev, Y. V., Subbotin, Y. A., Hnalkov, S. A., and Kravchenko, O. N. 1991. Portativny analizator karbonatov PAK-1 [Portable Analyzer of carbonates PAK-1] Khimia $v$ sel'skohoziastve 12:34-38.

Bure, V. M. 2007. Metodologia statisticheskogo analiza opytnyh dannyh [Methodology of statistical analysis of empirical data]; St. Petersburg University Press, Saint Petersburg, $141 \mathrm{pp}$.

Ivanov, A. F. and Ermokhin, Yu. I. 1990. O soderzhanii strontsia $v$ pochve i rasteniah $v$ rezul'tate primenenia razlichnyh form fosfornyh udobreni [Strontium content in soil and plants as affected by application of different forms of phosphorus fertilizer]; p. 164 in Proceedings of the XI All-Union Conference, Samarkand, Trace Elements in Biology and Their Use in Agriculture and Medicine.

Kabata-Pendias, A. and Pendias, H. 2001. Trace elements in soils and plants. Third edition. CRC Press. $331 \mathrm{pp}$.

Karpova, E. A. and Potatuyeva, J. A. 2004. Posledstvia primenenia razlichnyh form fosfornyh udobreni: strontsi $v$ sisteme dernovo-podzolistaya pochva-rastenia. [Consequences of application of various forms of phosphorus fertilizers: strontium in the system of sod-podzolic soil-plants]. Agrokhimia 1:91-96.

Khrustaleva, M.A. 2000. Biochimicheskoe izuchenie landshavtov Moskovskogo regiona [Biogeochemical Study of Landscapes in the Moscow Region]; pp. 185-186 in Proceedings of Third Russian Biogeochemical School: Geochemical Ecology and the Biogeochemical Study of Biosphere Taxon. Novosibirsk.

Lauk, E., Lauk, R., and Lauk, Y. 2004. Experimental planning and methods in regression analysis; pp. 58-64 in Proceedings of the $12^{\text {th }}$ International Conference on Mechanization of Field Experiments. St. Petersburg.

Lavrishchev, A.V. 2016. Izuchenie povedenia stabil'nogo strontsia $v$ agroekosistemah Severo-Zapada Rossii [Study of the behaviour of stable strontium in agro-ecosystems of the North-West of Russia]; PhD thesis, St. Petersburg Agrarian University, $272 \mathrm{pp}$.

Litvinovich, A. V., Lavrishchev, A. V., and Pavlova, O. Yu. 2013. The behavior of $\mathrm{Ca}$ and $\mathrm{Sr}$ in the soil-plant system from liming with a strontium-containing ameliorant; pp. 17-34 in Proceedings of the First International Congress on Soil Science: Soil-Water-Plant, Belgrade, Serbia 2013.

Litvinovich, A. V. and Nebolsina, Z. P. 2012. Prodolzhitel'nost deistvia meliorantov $v$ pochvah i effektivnost izvestkovania [The duration of action of ameliorants in soils and the effectiveness of liming]. Agrokhimia 10:79-94.

Litvinovich, A. V. and Pavlova, O. Y. 2010. Izmenenie velichiny pochvennoy kislotnosti $v$ processe vzaiomodeistvia me- liorantov s pochvami (po dannym laboratornyh I vegetacionnogo opyta) [Change of soil acidity value during the interaction of ameliorants with soil (laboratory and vegetation experiments)]. Agrokhimia 10:3-10.

Litvinovich, A. V., Pavlova, O. Yu., Lavrishchev, A. V., and Vitkovskaya S. E. 2005. Ekologicheskie aspekty izvestkovania pochv konversionnym melom [Ecological aspects of soil liming with conversion chalk]. Plodorodie 1:23-26.

Litvinovich, A. V., Pavlova, O.Yu., Maslova, A.I., and Lavrishchev, A. V. 2000. Nakoplenie stabil'nogo strontsia sel'skohozaistvennymi kul'turami pri izvestkovanii dernovo-podzolistyh pochv konversionnym melom [Accumulation of stable strontium by agricultural crops on soddy-podzolic soils limed with conversion chalk]. Agrokhimiya, 9:80-88.

Litvinovich, A.V., Pavlova, O. Yu.,Yuzmukhametov, D. N., and Lavrishchev, A. V. 2008. The migration capacity of stable strontium in Soddy-podzolic soils of the Russian northwest (data of simulation experiments). Eurasian Soil Science 41(5):502-508. https://doi.org/10.1134/ S1064229308050050

Myrvang, M. B., Heim, M., Krogstad, T., Almås, A.R., Gjengedal, E. 2017. The use of carbonatite rock powder as a liming agent. Journal of Plant Nutrition and Soil Science 180:326-335. https://doi.org/10.1002/jpln.201600455

Public Health Statement, 2004. Department of Health and Human Services, Public Health Service Agency for Toxic Substances and Disease Registry Strontium. CAS : 744024-6; Springfield, VA; www.atsdr.cdc.gov/

Qi, L., Qin, X., Li, F. M., Siddique, K. H., Brandl, H., Xu, J., and $\mathrm{Li}, \mathrm{X} .2015$. Uptake and distribution of stable strontium in 26 cultivars of three crop species: oats, wheat, and barley for their potential use in phytoremediation. International Journal of Phytoremediation 17(1-6):264-271. https://doi.org/10.1080/15226514.2014.898016

Semendyaeva, N. V. and Dobrotvorskaya, N. I. 1992. Strontsi i ftor v solontsovyh kompleksah Zapadnoi Sibiri [Strontium and Fluorine in Solonetzic Complexes of Western Siberia]; pp. 74-79 in Methods of Studying the Soil Cover Degraded under the Effect of Chemical Contamination: Proceedings of the Dokuchaev Soil Institute, Moscow.

Seregin, I. V. and Kozhevnikova, A. D. 2004. Transport, raspredelenie i toksicheskoe deistvie strontsia na rost prorostkov kukuruzy [Transport, distribution and toxic effect of strontium on the growth of corn seedlings]. Fiziologia rasteni $51(2): 241-248$.

Spravochnik himika [Chemist directory] 1964. Volume 3. Second edition, Moscow: Chemistry, 1005 pp.

Vinogradov, A. P. 1939. Geokhimicheskie issledovania v oblasti rasprostranenia urovskoi endemii [Geochemical Studies in the Region of the UrovEndemical Disease]; Doklady Akaemii Nauk USSR 23(1):2-11.

Yakushev, V.P. and Bure, V. 2003. Podhody k obnaruzheniyu karbonatov PAK-1 [Approaches to detect statistical dependencies PAK-1]. St. Petersburg University Press, $64 \mathrm{pp}$.

Yusan, S. and Erenturk, S. 2011. Adsorption Characterization of Strontium on PAN/Zeolite Composite Adsorbent. World Journal of Nuclear Science and Technology 1(1):7. https://doi.org/10.4236/wjnst.2011.11002 